\title{
Active Life of the Senior Citizens through Education
}

\author{
Saljakhutdin Fardievich Taziev ${ }^{1}$ \\ ${ }^{1}$ Elabuga Institute of Kazan Federal University, Republic of Tatarstan, Russia \\ Correspondence: Saljakhutdin Fardievich Taziev, Elabuga Institute of Kazan Federal University, Yelabuga, \\ Kazanskaya ul., 89, Republic of Tatarstan 423600, Russia.
}

\author{
Received: November 5, 2014 Accepted: December 5, 2014 Online Published: March 29, 2015 \\ doi:10.5539/ies.v8n4p134 \\ URL: http://dx.doi.org/10.5539/ies.v8n4p134
}

\begin{abstract}
The paper presents reasons for including the senior citizens into educational process, as well as active age model. Education, communication and leisure system for the senior citizens, implemented by Yelabuga municipal district, is presented as a requirement for model realization. A core of the paper is the Active Age Institute. Its program consists of organization of courses based on the senior citizens' requests and their involvement into educational work with the children and the youth. In its turn, work of future teachers with the senior citizens results in advance receiving by future specialists of integral system of knowledge concerning ageing social mechanisms and ways of increasing social mobility of the senior citizens.
\end{abstract}

Keywords: elderly age, senior citizen, active age model, education, communication and leisure system model for the senior citizens, The Active Age Institute

\section{Introduction}

Due to stable growth of the senior citizens in the country, new ideas of their role in social development are formed. On one side, wisdom and a feeling of satisfaction with life and fulfillment of trust, the highest level of personal integration are typical for the senior citizens. They make many-sided contribution to social development, welcome positive changes in life management and organization, show interest to social, cultural and economic life of the district, support solidarity of generations and keep intellectual and moral values, preserve capacity for a reasonable labor activity (Vladimirov, 2004; Shakhmatov, 1996). The poll, conducted in Yelabuga, Republic of Tatarstan, showed (350 senior citizens took part in the poll) that $81 \%$ of the senior citizens are ready to transfer experience and to fill in resources spent for their life support. Many people of older generation have high education and qualification level, they are ready to work and learn new professions that are in demand on a labor market. The results of the poll are as follows: $51 \%$ of the pollees would like to get an additional IT education, 46\%-medical, 23\%-construction-engineering, 17\%-legal, 13\%-historical, 10\%-pedagogical education, etc. The senior citizens are ready to take up those fields of activity that are not claimed by the youth, to share their knowledge with the peers and the youth: to discuss with young people their behavior- $56 \%$, to transfer religious knowledge $-47 \%$, to share professional skill- $71 \%$, to organize clubs $-28 \%$.

On the other side, changes due to innovation processes in Russian society and life of its citizens influence the status and well-being of the elderly people, which feel difficulties in adapting to dynamic economic and social-cultural conditions. The senior citizens need consultancies on the following issues: pension benefits-67\%, longevity and health culture-54\%, economy-34\%, politics (reasons of the USSR collapse, external policy of Russia, etc.) $-61 \%$, law (rights of the elderly people, employment, housing and public utilities benefits, defense against fraud, etc.)- $86 \%$. The senior citizens require help taking into account differentiation, complexity of their problems, their needs and demands (Bakhmetova \& Ivankova, 2004; Sukhova, 2003).

One of the actively developing ways to solve these problems is different special educational programs for the senior citizens. For today, there are plenty of universities for the third age people in Europe and America. They have different educational programs and include different modes of study both paid and free (Malone, 1999; Field, 2011; Minigalieva, 2004; Allen \& Unwin, 2002; Imel \& Merriam, 2001). Based on the research of the senior citizens' subjective view on the essence of educational processes, conducted by M. E. Elyutina and E. E. Chekanova, the authors pointed out three types of gerontological groups having different strategies in educational activity: the $1^{\text {st }}$ group is activity-oriented, has demand for creativity, inexhaustible interests, that's why education is an inherent value for this group; the $2^{\text {nd }}$ group thinks that the main form of education is clubs; 
the $3 \mathrm{~d}$ group includes the elderly people, which consume educational services but do not see their prospects in educational activity. Thus, forms of including the senior citizens into educational process will largely depend on their subjective view on the essence of educational processes (Elyutina \& Chekanova, 2003).

Literature analysis and the conducted poll enabled us to point out the following reasons for required involvement of the senior citizens into educational process: advance training, getting of the $2^{\text {nd }}$ higher education (Taranchuk, 2005; Kholostova, 2002); need for functional literacy: to be familiar with amenities and to be able to use them, for example, computer literacy; need for pleasant leisure activities, possibility to find an interesting circle of contacts, etc.

\section{Methods}

Thus, "education of the senior citizens is a constituent part of education, which aims at promoting all-around development of a man when he attains pre- and pension age" (Sukhobskaya \& Bozhko, 1998).

Education in the elderly age is widely understood in European countries, as any activity directed to personal self-actualization. State and non-state institutions, as well as commercial entities are engaged in education of the senior citizens. Care for elder people is not only brought to a level of state policy, but is reflected in all spheres of public conscience. It stands to reason that they are not called "old people" or "third age people". They are respectfully called "Senioren" (Agapova, 2000). As Y. Klergk underlines, successful education of the senior citizens, for example, in Holland, lies in the fact that the senior citizens are considered as an interesting target group: they are not consumers of care, they are buyers of educational products and spare time (Klergk, 2000). Education for adults is considered like a process, when adults are busy with systematic and continuous training in order to get new knowledge, skills, relations or values (Merriam, \& Brockett, 2007). At the same time, adults run across some obstacles, when it comes to study. Adult students suffer from lack of time balance and family needs, financial status or lack of transport (Phipps, Prieto, \& Ndinguri, 2013).

Taking into account all above-mentioned information, a municipal public project The Active Age Institute, developed by the scientists of Elabuga Institute of Kazan Federal University (EI KFU) was established and introduced in Yelabuga.

This project is considered as a program for developing cooperation of social institutions with the senior citizens and as an important strategic document reviewing transition mechanisms from one state to another. During development we set the following tasks:

1) To fix the attained level of functioning of the senior citizens life organization system, and to determine reference point for future development steps.

2) To determine and describe image of targeted future for the municipal senior citizens system, its structure, functioning and development parameters corresponding to the needs, values and possibilities of the society.

3) To determine strategy and tactics of transition from attained level of the senior citizens system and each component to future strategy of the renewed system functioning.

This project presents one of the approaches to development of the senior citizens education and life system in the Republic of Tatarstan.

While developing this project the authors determined several principle positions making the basis of the paper.

1) The municipal senior citizens system is presented in the project as an open social system consisting of some sub-systems which are fixed as strategic directions of development.

2) According to this logic we built organizational structure of the project. Goals, tasks, priorities, estimated results of each strategic direction have strong interrelations and present some integrity.

3) The project specifies general directions, describes the most general processes, determines regularity, and prompt actions are described in the current plan of the work.

Thus, goals of the project are as follows:

1) To develop and approve mechanism of interaction with the senior citizens.

2) To increase quality of the senior citizens life organization.

There are quite a lot institutions and organization in the town dealing with the senior citizens problems. Our main task is to unite their efforts and to create a unified informational-and-organizational system of work with the pensioners, so that each of them could find a field of application of their forces and possibilities, lead an active life. 
The concept as an integral image of the system consists of two main blocks. "Future model" with regard to our project consists of the following components:

1) "Active age model";

2) "Image (model) of the senior citizens education, communication and leisure system".

Active age model

\begin{tabular}{|c|c|}
\hline Spheres & Results of cultural self-determination \\
\hline Civil self-determination & $\begin{array}{l}\text { I know and study national languages (Russian and Tatar). } \\
\text { I can critically comprehend social life events. } \\
\text { I know about different forms of political and economic life of the society. } \\
\text { I know my rights and obligations and can perform them. I observe the law. } \\
\text { I participate in elections actively. } \\
\text { I have need for service to the country and people. } \\
\text { I follow norms and traditions of Yelabuga citizens. }\end{array}$ \\
\hline National self-determination & $\begin{array}{l}\text { I am proud that I present ... nation. } \\
\text { I know and study national holidays, traditions, manners and customs. } \\
\text { I participate in national holidays and actions with pleasure. } \\
\text { I participate in national public associations activities. } \\
\text { I study history and culture of my nation. } \\
\text { I participate in international public associations activities. }\end{array}$ \\
\hline $\begin{array}{l}\text { Environmental } \\
\text { self-determination }\end{array}$ & $\begin{array}{l}\text { I aim at saving environment in everyday life and labor. } \\
\text { I help the nature. }\end{array}$ \\
\hline Aesthetic self-determination & $\begin{array}{l}\text { I have an aesthetic consciousness. } \\
\text { I have taste, interest, aesthetic ideal. } \\
\text { I see beautiful things around me and appreciate them. } \\
\text { I can create aesthetic values (works of art). } \\
\text { I aim at harmony and perfection. } \\
\text { I visit cultural centers. }\end{array}$ \\
\hline Value self-determination & $\begin{array}{l}\text { I know rules and norms, approved by the society, and can keep them. } \\
\text { I can make decisions at moral choice. } \\
\text { I am kind towards other people. } \\
\text { I have need for defending my points of view and beliefs. } \\
\text { I follow rules and obligations consciously. } \\
\text { I understand human moral and intellectual values. }\end{array}$ \\
\hline Behavior self-determination & $\begin{array}{l}\text { I can live with other people. } \\
\text { I know basics of communication and can communicate with people. } \\
\text { I have sense of proportion in communication. } \\
\text { I can control myself. } \\
\text { I have my own style, image. } \\
\text { I am independent. } \\
\text { I follow cultural behaviour, control myself. }\end{array}$ \\
\hline Health & I can plan my day. \\
\hline
\end{tabular}




\begin{tabular}{|c|c|}
\hline self-determination & $\begin{array}{l}\text { I am physically active. } \\
\text { I can follow sanitary-hygiene rules. } \\
\text { I lead a healthy life. } \\
\text { I preserve my health. } \\
\text { I take care of my health. } \\
\text { I can allocate my time for training and rest in a right way. } \\
\text { I have no pernicious habits. } \\
\text { My attitude towards pernicious habits is negative. }\end{array}$ \\
\hline $\begin{array}{l}\text { Labor and professional } \\
\text { self-determination }\end{array}$ & $\begin{array}{l}\text { I know rules of conduct in labor and professional activity and can follow them. } \\
\text { I know safety rules and can follow them. } \\
\text { I have teamwork skills. } \\
\text { I am ready to work. }\end{array}$ \\
\hline $\begin{array}{l}\text { Intellectual } \\
\text { self-determination }\end{array}$ & $\begin{array}{l}\text { I admit importance of knowledge in life. } \\
\text { I practice self-education. } \\
\text { I visit senior citizens courses with pleasure. }\end{array}$ \\
\hline Informational literacy & $\begin{array}{l}\text { I know computer components. } \\
\text { I can find files and folders. } \\
\text { I can convert information. } \\
\text { I can use standard programs. } \\
\text { I can work in Internet. }\end{array}$ \\
\hline
\end{tabular}

"Image (model) of the senior citizens education, communication and leisure system" we consider as a requirement to implement "the active age model".

\begin{tabular}{|c|c|}
\hline \multicolumn{2}{|l|}{ The senior citizens education system } \\
\hline Conceptual reference & Estimated conceptual result \\
\hline $\begin{array}{l}\text { Lack of the senior citizens education } \\
\text { system }\end{array}$ & $\begin{array}{l}\text { Available unified municipal education system for the senior citizens. } \\
\text { Key competence and self-development orientation of the education } \\
\text { system, life change and future planning preparedness, and } \\
\text { self-education improvement. }\end{array}$ \\
\hline \multicolumn{2}{|c|}{ The senior citizens communication and leisure system } \\
\hline Conceptual reference & Estimated conceptual result \\
\hline $\begin{array}{l}\text { The system has fragmentary, event } \\
\text { character. }\end{array}$ & $\begin{array}{l}\text { The senior citizens communication and leisure system is the priority. } \\
\text { It has scientific and planning character. }\end{array}$ \\
\hline \multicolumn{2}{|c|}{ System of work with the personnel from educational, sport and cultural institutions } \\
\hline Conceptual reference & Estimated conceptual result \\
\hline $\begin{array}{l}\text { Lack of the system of work with the } \\
\text { personnel }\end{array}$ & $\begin{array}{l}\text { Development and implementation of a common curriculum and } \\
\text { educational and social-pedagogical programs of the Active Age } \\
\text { Institute. }\end{array}$ \\
\hline \multicolumn{2}{|c|}{ The resource system as the strategic management object } \\
\hline Conceptual reference & Estimated conceptual result \\
\hline $\begin{array}{l}\text { Legal, logistic, information-methodical } \\
\text { support has fragmentary character. }\end{array}$ & $\begin{array}{l}\text { Adjustment of the senior citizens education, communication and } \\
\text { leisure system in accordance with modern legal support. } \\
\text { Creation of an information education electronic net for participants }\end{array}$ \\
\hline
\end{tabular}


of the educational-social-pedagogical process.

Thus, in the active age model we tried to determine the main fields of human self-determination that enabled us to set forth an idea on establishing The Active Age Institute, to reveal its actual values, mission and principles.

Mission of the Institute-being the senior citizens education, communication and leisure center to provide free quality educational and social services for the senior citizens meeting municipal requirements.

Strategic goal of the Institute-to form the senior citizens active life by means of involving them into educational and social activity, organizing communication and leisure for them.

The main activities:

1) Development of the senior citizens education system.

2) Development of the senior citizens communication and leisure system.

3) Involvement of the senior citizens into active social and pedagogical work with the younger generation.

\section{Results and Discussions}

Thus, The Active Age Institute (AAI) in Yelabuga is an independent public organization uniting on a voluntary basis work collectives from the social protection, education, sport and culture institutions, scientists, technicians, practitioners and students employed in education and other allied spheres.

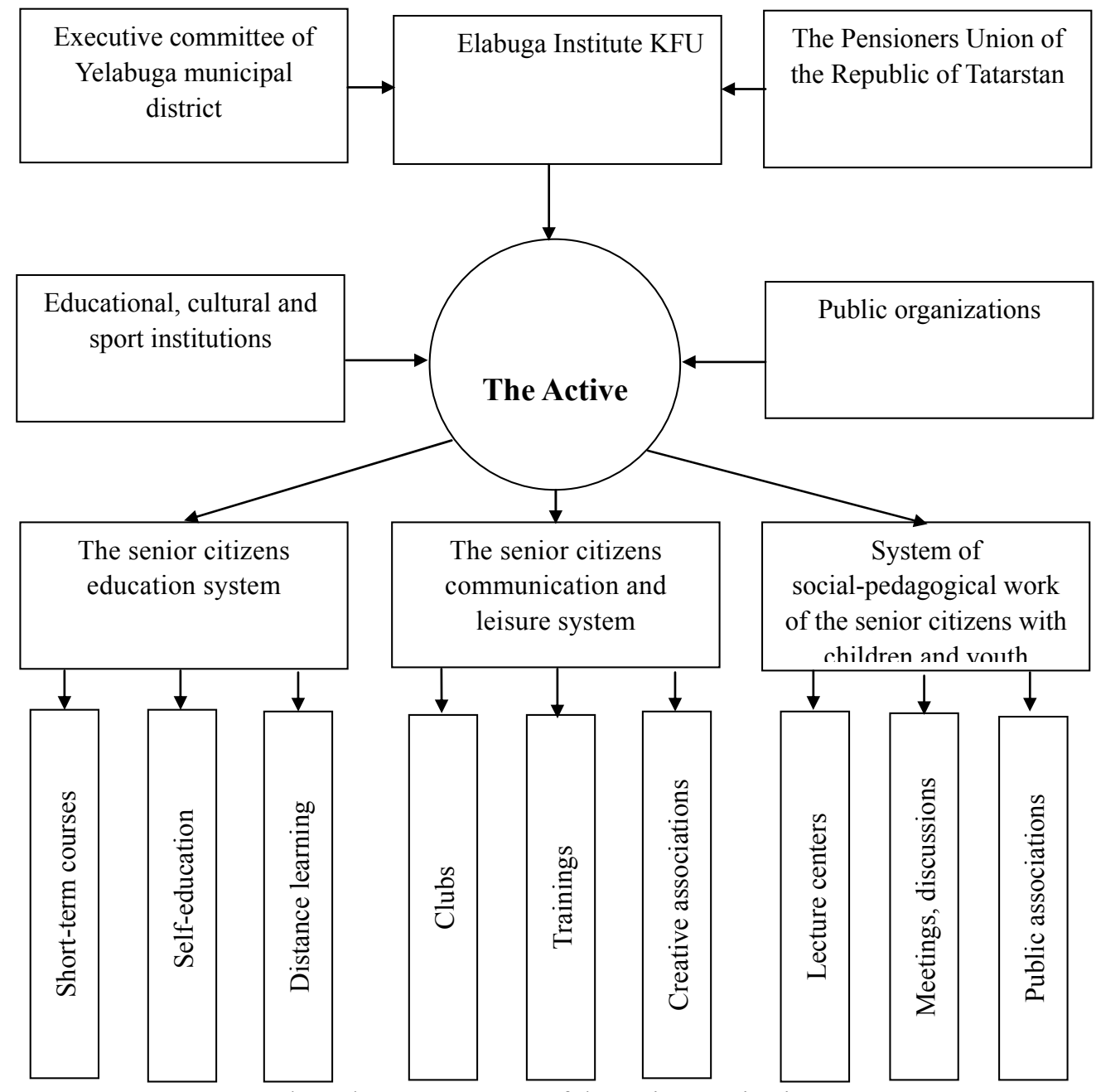

Flow chart 1. Structure of the active age institute 
The AAI is officially presented twice a year. The main task for this non-standard but current innovation is to involve the pensioners into active life and communication. During presentation the senior citizens may not only know all details of the project, but enroll to any course of their choice.

PC courses rank the first among the pensioners. Although from the very beginning the senior citizens are afraid, but they are committed to conquer virtual space of the Internet and computer itself. "I wished to take courses long ago, and now it's possible to do at the Institute next to my house. We visit them with pleasure", says a participant of the project. Students of EI KFU teach pensioners to work in the Internet, most of all they are interested in e-mail creation. "It's a boundless possibility for communication. Friends and relatives of many people are "scattered" far outside the republic and even the country. It's a possibility to understand our children and grandchildren more, to establish good contacts between us", say course participants.

The pensioners are taught to use such sites as "Senior Information World". This site has plenty of useful Internet-resources with brief annotations, pictures where they can find information as follows: What cosmetics do senior Frenchwomen use? What sports are included into the International Senior Sport Games? What clothes do senior English women wear? What pensions do Germans have? How do senior Swiss spend leisure time? How to enter the senior international dating site? Participants of the courses read the following electronic magazines with great interest: Pro Senior (Germany), Boomer Times and Senior Life (USA), Fifty-Five Plus (Canada), Zeitlupe (Switzerland), LiberIta (Italy), Notre temps (France), etc., which are characterized by plenty of useful information in medicine, fight with ageing and new achievements in longevity.

Participants of the courses find the pensioners virtual PC academy very useful, where they get full answers to the following questions of interest: Why does a pensioner need a PC? How to keep a blog, to print memoirs, to create a photo gallery, to watch favorite films several times, Internet earnings, etc.

English, German, Tatar, Valeology, Practical Psychology, Regional Studies through History, Legal Literacy, PT, Choreography courses are also in demand among the senior citizens of Yelabuga.

German courses for beginners are for those people, who have never studied German or studied it a bit but have no systematic knowledge. Concept of the course German for Beginners is to create conditions for learning everyday communication vocabulary, to understand speech and to build a clear structural grammatical base. German courses for beginners correspond to $0>\mathrm{A} 1$ level of the new European classification.

Objective of the English course is to renew speech skills of the participants, who studied English at schools, colleges or higher institutions but lost these skills in the succeeding years. The program includes four topics (my family, house, gardening, meals), within which the participants are to renew their active vocabulary and to form speaking, listening, reading and writing skills.

Psychologists of EI KFU give classes to the senior citizens in order to decrease their level of aggression and overcome depression. Psychologists conduct psychotechnic games and exercises, talks, art-therapy, relaxation, breathing exercises, etc. with the senior citizen. Such classes help pensioners to form positive attitude to life, themselves and people.

The gym of the Institute became a favorite place for many pensioners in the town. Program of the course Physical Training for Active Age enables to solve tasks of pensioners' physical education during the whole course forming their ideas on exercises, physical training, possibilities to improve work efficiency and health. Peculiarity of the program is that it is created for people having problems with health. So, we realize the task of forming need for health and independent physical training.

The $1^{\text {st }}$ Spartakiad of the All-Russian public organization Union of Pensioners of Russia took place in Kazan in May 2013, where participated a team of 15 Yelabuga citizens. There were 8 competitive sports and our fellow-townsmen became total winners of this sport event among 43 Tatar teams.

Social life of old people becomes narrower and narrower due to loss of relatives, friends and spouses, bad health that limits their activity. That's why they turn to their peers and the youth. Peers have common interests, problems and even diseases. Thus, as the teachers, employees and students of EI KFU say, their "students" never hurry to leave the lecture room and ask additional questions, share their views, not to mention their diligence at doing homework. And the participants of the courses themselves admire the project. The classes take place maximum 2 times a week, no control of attendance, and instead of endless tests and exams there is only one test on 4- months learning results in a form of creative project.

Beside courses for the senior citizens, there is a club activity on the basis of EI KFU. For example, permanent members of the local history club get acquainted with exploring and collective practice on the basis of the Museum of History of the Institute, Archeological Museum, Museum of Yelabuga Merchantry, they are involved 
in collecting, processing and publication of verbal sources. The elder generation gets interest in such topics as "Yelabuga land during the Ancient times and the Middle Age", "Merchant Yelabuga", "The mayor in the structure of municipal self-government (the second half of the XIX ${ }^{\text {th }}$-beginning of the XX ${ }^{\text {th }}$ century", "History of education in Yelabuga", etc.

Involvement of elder generation into educational work with the children and the youth is a constituent part of AAI program. With this purpose many creative groups of the senior citizens "moved" to educational institutions. Thus, a literary-creative association "Chulman" actively works with participants in order to find out and develop their gifts in literature and music, implements common projects for children and adults. Former teachers of EI KFU continuously help students to prepare and hold conferences, themed nights, contests, and they are happy and satisfied with this. Communication with the youth has a special meaning for such people, when the youth congratulates them with holidays, tells about life. It brings elder people to life and they understand their place in the society.

In its turn, work of students with the senior citizens in conditions of the modern Institute results in advance learning by future specialists of the integral system of knowledge about ageing social mechanisms and tools for increasing social mobility of the senior citizens, it teaches them to model and solve situations for their social support. "Young teachers", say participants of the project, "hold courses like professionals, we don't even feel that they are students. They are distinguished by respect to elder people, diligence and tact."

Beside such classes with the senior citizens, teachers and students of EI KFU involve other schools and institutions of the town in this activity. College of Culture and Arts, for example, organizes vocal, choreography and art lessons for the senior citizens of Yelabuga. Medical College organizes lessons on valeology, first aid measures, etc.

Such work unites efforts of teachers and students of the Institute and general public of the town in order to create a unified system of work enabling the senior citizens to feel needed and interesting for modern society, equal to realize their needs and dreams in terms of developing their creative and communicative skills. Thanks to common activity of elder and young people AAI promotes breakdown of barriers between generations, understanding of the senior citizens and the youth what benefits, experience and interests they may give to each other.

Our experience shows that old age can be as attractive as other periods of human life with correct physical and psychological attitude and good relations with others. Recognition of own needlessness is a powerful factor of ageing. It is good when a person has reasonable age sense. It is achieved due to education, which is to teach the senior citizens values of democracy, adaptation to new social and economic conditions, to take informed decisions on all levels, to protect their rights without prejudice to rights of others, to treat different systems of behavior and values of multicultural Russian society with respect and patience. It is necessary to develop the seniors' talents for self-education and reception of new things by means of all forms of education, so that a person could solve his problems on his own or with the peers or the youth not relaying totally on the state.

\section{Conclusion}

So, modern educational services for the senior citizens aim at saving mobility, activity, zest for life of the participants, promoting their participation in public life and developing their peculiarities, self-realization. Due to AAI the senior citizens take part in social life, have possibility to keep old friendship or make new contacts, and students may implement in practice gained knowledge, care and respect elder people. Young people caring for a senior will always have understanding of the seniors' demands and desire to help such people. Nowadays, when people forget about the main human values in chase of carrier and money it is important to remind about them.

It is necessary to involve education, culture and sport specialists, businessmen, public organizations in educational work with the senior citizens; to create system of work with the senior citizens studying their needs and demands; to involve students and working youth in development and implementation of innovative projects concerning work with war and labor veterans, people living at rest homes, as well as different support of lonely and sick senior citizens. For example, the project I Have A Grandfather (Grandmother) could promote closer relations between the orphans, children from boarding schools and the senior citizens having no children of their own. The project Writing Stories of Interesting People could help the youth to practice virtue studying both glorious war and labour feats of their ancestors and their bitter experience, etc. One should develop the distance learning system for the senior citizens in order to ensure continuous and affordable education for different categories of adult population. 
Thus, concept of our project is based on the thesis: "Modern system of work with the senior citizens is to promote their active life through continuous education, organized communication and leisure, and participation of the youth is to become a gain in moral culture experience" (Merzon \& Taziev, 2013). Education in the third age is to promote satisfaction in the main needs: emotional, cognitive, to be respected, to feel social usefulness, to bear responsibilities for any decisions taken. Cohesion of the senior citizens and idea of their social participation are underlined here. "Education in this age is a link between the past, the present and the future needs of the seniors" (Findeizen, 2002).

\section{References}

Agapova, O. (2000, November 21-25). Education of the senior citizens in Russian society: To problem definition. Education of the senior citizens: Prospects for the society and a man. Materials of the International Conference, Moscow, Saint Petersburg, 53-62.

Bakhmetova, G., \& Ivankova, L. (2004). Modern problems of population ageing in the world: Tendencies, prospects, relations between generations. Moscow: MAKS Press.

Burns, R. (2002). The Adult Learner at Work: The Challenges of Lifelong Education in the New Millennium (2nd ed.). Allen \& Unwin.

Edelson, P., \& Malone, P. (1999). Enhancing Creativity in Adult and Continuing Education: Innovative Approaches, Methods, and Ideas. Jossey-Bass.

Elyutina, M., \& Chekanova, E. (2003). Aged person in education space of the modern society. Social studies, $7(231), 43-49$.

Field, J. (2011). Adult learning, health and well-being-changing lives. Adult Learner, 13-25.

Findeizen, D. (2002). Education of the senior citizens in Slovenia: Problems and prospects. Education for the seniors. Regions of the project. Exchange of experience. Prospects. Materials of interregional seminar, Chelyabinsk, Saint Petersburg, 4-14.

Imel, S., \& Merriam, S. (2001). The New Update on Adult Learning Theory: New Directions for Adult and Continuing Education. Jossey-Bass.

Kholostova, E. (2002). Social work with the senior citizens: Work book. Moscow: Publishing-trading corporation "Dashkov and Co.".

Klergk, Y. (2000, November 21-25). Education of the senior citizens in Holland. Education of the senior citizens: Prospects for the society and a man. Materials of the International Conference, Moscow, Saint Petersburg, 45-52.

Merzon, E., \& Taziev, S. (2013). The Active Age Institute as a form of organization of the educational and social-pedagogical work with the senior citizen. Modern problems of science and education, 1 . Retrieved October 26, 2014, from http://www.science-education.ru

Minigalieva, G. (2004). Social policy with regard to the senior citizens. Psychology of maturity and aging, 1(25), 111-124.

Phipps, S., Prieto, L., \& Ndinguri, E. (2013). Teaching an old dog new tricks: Investigating how age, ability and self-efficacy influence intentions to learn and learning among participants in adult education. Academy of Educational Leadership Journal, 17(1), 13-25.

Pisarev, A. (2005). Demographic ageing in Russia: life of the senior citizens. Moscow: TsSP.

Shakhmatov, N. (1996). Psychical ageing: Happy and painful. Moscow: Medicine.

Sharan, M., \& Ralph, B. (2007). The Profession and Practice of Adult Education: An Introduction. Jossey-Bass.

Sukhobskaya, G., \& Bozhko, N. (1998). Aged person in modern world: Textbook for social teachers. Saint Petersburg: IOV EAO, "Tuskarora".

Sukhova, L. (2003). Organization of leisure and spare time for the senior citizens. Old age problems: Moral, medical and social aspects. Moscow: Publishing house "Svyato-Dimitrievskoe uchilishche sester miloserdiya".

Taranchuk, A. (2005). Live and learn. Studying abroad, 9, 26-29.

Vladimirov, D. (2004). The older generation as an economic growth factor of Russia. Moscow. 


\section{Copyrights}

Copyright for this article is retained by the author(s), with first publication rights granted to the journal.

This is an open-access article distributed under the terms and conditions of the Creative Commons Attribution license (http://creativecommons.org/licenses/by/3.0/). 